\title{
Let's Write About the Interference in Scientific Research on COVID-19 in Turkey: Is This Real or a Biased Dream
}

\author{
(1) Gülistan Bahat Öztürk1， (1) Alpay Medetalibeyoğlu², (1) Tufan Tükek2, (1) Mehmet Akif Karan1 \\ 1 Istanbul University Istanbul Faculty of Medicine, Department of Geriatrics Medicine, Istanbul, Turkey \\ 2istanbul University Istanbul Faculty of Medicine, Department of Internal Medicine, Istanbul, Turkey
}

We have read the article by Bayram et al. (1) entitled "Interference in scientific research on Coronavirus disease-2019 (COVID-19) in Turkey" with great interest. There, the authors made may claims, i) The authors declared that tension soon started building among the public sector and medical and scientific organizations due to the Ministry of Health's lack of transparency, its reluctance to share basic data, and its refusal to collaborate. There were also concerns about the shortage of personal protective equipment (PPE) for health-care workers.

We would like to declare the situation we have been experiencing, from the beginning of this great pandemic in Turkey, from Istanbul University Istanbul Medical School which is the only university that has been declared within the first 500 ranking among the Academic Ranking of World Universities (2). We are completely free in sharing our data and suggestions with the rest of the World in order to improve the fight against the unprecedented COVID-19 pandemic. We have published two articles $(3,4)$ which outlines the polymerase chain reaction (PCR) positive cases from our institution which has identified the first COVID-19 case in our country on March 1, 2020, and had become a major center of the pandemic in Istanbul. The other 37 articles among which we compare the data of the PCR positive and negative cases and early follow-up of more than 600 cases in our post-covid follow-up the outpatient clinic is on the way and they have all received approval from the local ethics committee and the Ministry of Health as well.

ii) Another the claim of the authors was a shortage of PPE for health-workers. This is not true in our institution. Furthermore, the Turkish Ministry of Health has supplied not only the health care workers but all of each individual in the general population with surgical masks which were given freely by the pharmacies or with free of charge delivery to the individual settings ondemand $(5,6)$. This happened all through the country population which is more than 80 million by number. Another important point is that all patients and any exempted visitors have been recommended to absolutely bring or be given masks (e.g., nonmedical or cloth masks) to wear upon entry into the health care setting for universal control (7). It has been declared that, when supplies are limited, cloth masks maybe reasonable for certain workers in health care settings.

The World Health Organization (WHO) recommends maskwearing where there is the widespread transmission and social distancing is difficult $(8,9)$. The WHO advises that most individuals in the community wears a non-medical mask (e.g., a cloth or fabric mask). In the United States, the centres for disease control $(C D C)$ and prevention $C D C$ also recommends that individuals wear a mask when in public settings or around other people who are not household contacts, particularly when social distancing is difficult to achieve (10). Noteworthy, the CDC specifies that the mask recommendation does not include medical masks, which should be reserved for health care workers (11). Considering the economical power of the United States, these approaches clearly show that there is no shortage of PPE in Turkey, which directly provides the surgical medical masks to their all citizens without any charge and without any consideration of social security insurance, being immigrant or not.

Address for Correspondence: Gülistan Bahat Öztürk, İstanbul University İstanbul Faculty of Medicine, Department of Geriatrics Medicine, İstanbul, Turkey

Phone: +90 2124142000 E-mail: gbahat-ozturk@istanbul.edu.tr ORCID: orcid.org/0000-0001-5343-9795

Received: 1 Oct, 2020 Accepted: 9 Oct, 2020

Cite this article as: Öztürk Bahat G, Medetalibeyoğlu A, Tükek T, Karan MA. Let's Write About the Interference in Scientific Research on COVID-19 in Turkey: Is This Real or a Biased Dream. Eur J Geriatr Gerontol 2020;2(3):62-64

๑Copyright 2020 by the Academic Geriatrics Society / European Journal of Geriatrics and Gerontology published by Galenos Publishing House. 
iii) The authors claimed that "the final stroke came with the control of COVID-19 research by the Ministry of Health. Despite the great interest in research on COVID-19 in Turkey by researchers and physicians, the Turkish Ministry of Health announced a mandatory application for permission for research on COVID-19, before any application is made to ethics committees. This the unprecedented decision was against the constitution and laws regulating research activities in Turkey. It appears that most submitted projects have been approved by the Ministry of Health, but some projects, including a large, a multicentre observational study by the Turkish Thoracic Society, have been rejected without any clear explanation."

As authors noted, most of the submitted projects have been approved by the Ministry of Health. We would like to express that we had no difficulty in the approval of any projects by the Ministry. This detail for the Turkish Thoracic Society maybe, most probably, related to their own board, which proves to be very biased in their scientific conclusions. This approach is clearly against the rules of good science.

As the authors noted "the regular procedure for research activities in Turkey is well defined. In keeping with the international regulations, researchers must get approval from the independent ethics committee." This is a standard that has been applied to all researchers in Turkey. It should be noted that it is required for the researchers to be registered to clinical trials web site in many cases in order to be able to derive a good and trustable data and study. As COVID-19 is a global health concern for the country and the world, it is not surprising that the COVID studies should receive permission from the Ministry of health. This approach could only be appreciated as the scientists that aim to derive good data and trustable, ethical studies. Furthermore, the Minister of Health, who has been directing this health crisis with great success from the beginning of the pandemic, called Turkish scientists to publish their data as soon as possible, publicly.

The authors did not write anything about the successful management of COVID-19 health demand in Turkey. We had no shortage of hospital beds, no shortage of intensive care unit beds. These health services have been supplied to every single individual that reside in Turkey, who may be immigrant even with no identity number. We had no deaths due to a shortage of medical care. This point has been appreciated many times (12).

Another point is that the Turkish Thoracic Society has been well criticized by their such biased declaration by the respiratory physicians themselves. It would be expected by the board members of the society to yield a general view from the respiratory physicians, as they owe this to the scientific committee they claim that they already represent. In fact, such a declaration without any survey among respiratory physicians is another major fault of the society.
In conclusion, we, as Istanbul University Istanbul Medical Faculty, are greatly worried and concerned about the biased approach of the few members of the Turkish Thoracic Society that fails to represent the respiratory physicians.

\section{Ethics}

Peer-review: Externally and internally peer-reviewed.

\section{Authorship Contributions}

Concept: G.B.Ö., M.A.K., Design: G.B.Ö., T.T., Data Collection or Processing: G.B.Ö., A.M., Analysis or Interpretation: T.T., Literature Search: G.B.Ö., A.M., Writing: G.B.Ö., A.M., M.A.K.

Conflict of Interest: No conflict of interest was declared by the authors.

Financial Disclosure: The authors declared that this study received no financial support.

\section{References}

1. Bayram H, Köktürk N, Elbek 0 , Kılınç $O$, Sayıner A, Dağlı E, Turkish Thoracic Society. Interference in scientific research on COVID-19 in Turkey. Lancet 2020;396:463-464.

2. Academic Ranking of World Universities 2020 Last Accessed Date: 17.08.2020 Available from: http://www.shanghairanking.com/ARWU2020. html.

3. Bahat G. COVID-19 and the Renin Angiotensin System: Implications for the Older Adults. J Nutr Health Aging 2020;24:699-704.

4. Medetalibeyoğlu A, Senkal N, Kose M, Catma Y, Bilge Caparali E, Erelel M, Oral Oncul M, Bahat G, Tukek TI. Older adults hospitalized with Covid-19: Clinical characteristics and early outcomes from a single center in Istanbul, Turkey. Research Square 2020:1-21.

5. https://www.turkiye.gov.tr/

6. https://maske.epttavm.com/

7. Centers for Disease Control and Prevention. Interim Infection Prevention and Control Recommendations for Healthcare Personnel During the Coronavirus Disease 2019 (COVID-19) Pandemic. Last Accessed Date: 02.07.2020. Available from: https://www.cdc.gov/coronavirus/2019-nCoV/ hcp/infection-control.html.

8. WHO. Advice on the use of masks in the context of COVID-19. Last Accessed Date: 05.06.2020. Available from: https://www.who.int/publications/i/item/ advice-on-the-use-of-masks-in-the-community-during-home-care-andin-healthcare-settings-in-the-context-of-the-novel-coronavirus-(2019ncov)-outbreak (Accessed on June 08, 2020)

9. McIntosh K, Hirsch MS, Bloom A. Coronavirus disease 2019 (COVID-19): Epidemiology, virology, and prevention. UpToDate. Last Accessed Date: 17.09.2020. Available from: https: //www.uptodate. com/contents/coronavirus-disease-2019-covid-19-epidemiologyvirology-and-prevention?search $=$ covid $\% 20$ mask $\% 20$ CDC $\% 20$ cloth \&tsectionRank=1\&usage_type $=$ default $\&$ tanchor $=H 1466934285 \&$ tsource $=$ ma chine Learning \&tselected Title=3 150\&tdisplay_rank=3\#H1299415271; accessed on August 17, 2020).

10. Centers for Disease Control and Prevention. Considerations for Wearing Masks: Help Slow the Spread of COVID-19. Last Accessed Date: 12.09.2020. Available from: https://www.cdc.gov/coronavirus/2019-ncov/preventgetting-sick/cloth-face-cover.html

11. McIntosh K, Hirsch MS, Bloom A. Coronavirus disease 2019 (COVID-19): Epidemiology, virology, and prevention. UpToDate. 
Last Accessed Date: 17.08.2020. Available from: https: //www. uptodate.com/contents/coronavirus-disease-2019-covid-19epidemiology-virology-and-prevention?search $=$ covid $\% 20$ mask $\%$ 20CDC\%20cloth\&section Rank=1 \&tusage_type=default\&anchor $=$
$\mathrm{H} 1466934285 \mathrm{t}$ tsource $=$ machineLearning tselectedTitle $=3 \sim 150 \mathrm{ftdisplay}$ rank=3\#H1299415271; accessed on August 17, 2020).

12. "Turkey's public health system faces coronavirus pandemic". DW News. 7 May 2020. Retrieved 10 May 2020 